\title{
Influence of different fat supplements on digestibility and ruminal digestion in cows
}

\author{
M Doreau 1, Y Chilliard 1, D Bauchart 2, B Michalet-Doreau 3
}

With the technical assistance of $\mathrm{J}$ Fléchet ${ }^{1}, \mathrm{R}$ Lefaivre ${ }^{1}, \mathrm{C}$ Legay ${ }^{2}, \mathrm{M}$ Meyer ${ }^{2}, \mathrm{~A}$ Ollier 1

\author{
1 INRA, Laboratoire de la Lactation et de l'Elevage des Ruminants; \\ 2 Unité de Recherches sur les Métabolismes énergétique et lipidique, \\ 3 Unité de Recherches sur la Valeur alimentaire, Centre de Recherches \\ de Clermont-Ferrand-Theix, F 63122 Saint Genès Champanelle, France
}

(Received 11 December 1989; accepted 7 December 1990)

\begin{abstract}
Summary - In two trials each using 3 cows fitted with, rument cannulas, the effects of different lipid supplements on digestibility and ruminal digestion were analyzed. In trial 1, a control diet based on maize silage (C1) was compared to the same diet with a supplement of crude (untreated) bone fat (UF) and with a crystalline animal fat (CF). In trial 2, a control diet (C2) similar to diet $\mathrm{C} 1$ was compared to the same diet with a supplement of protein-coated (encapsulated) fat (EF). Fatty acid content in dry matter was $2.5 \%$ for control diets, 8.1 to $9.1 \%$ for supplemented diets. Apparent digestibility of nutrients, $\mathrm{pH}$ and volatile fatty acids in rumen juice, in sacco degradability of dry matter and cell walls were determined.

Fat supply decreased organic matter digestibility in trial $1(76.4,67.8$ and $68.8 \%$ in diets $\mathrm{C1}$, UF and $\mathrm{CF}$ ) and in trial 2 (74.1 and $68.1 \%$ in diets $\mathrm{C} 2$ and EF). This decrease was due to a strongly negative action on cell wall digestion: $69.1,53.7 \%$ and 57.3 in diets C1, UF and CF, 62.9 and $53.6 \%$ in diets $\mathrm{C} 2$ and EF, for NDF digestibility, and was related to a decrease in total volatile fatty acid concentration before feeding: $67.4,46.7$ and $47.7 \mathrm{mM}$ in diets $\mathrm{C} 1$, UF and CF, 61.1 and $54.6 \mathrm{mM}$ in diets $\mathrm{C} 2$ and EF. Acetate and butyrate decreased and propionate increased with lipid supply. The negative effect of fat on in sacco dry matter and cell wall degradation was moderate.
\end{abstract}

cow / digestion / "protected" fats

Résumé - Influence de différents suppléments lipidiques sur la digestibilité et la digestion ruminale chez la vache. Deux essais ont été menés, chacun avec 3 vaches porteuses de fistules du rumen, en vue d'analyser les effets de différents suppléments lipidiques sur la digestion. Dans l'essai 1, un régime témoin à base d'ensilage de maïs $\left(T_{1}\right)$ a été comparé au même régime avec une supplémentation en graisse d'os de bovins non traitée technologiquement (LNT) ou en graisses animales cristallisées (LC). Dans l'essai 2, un régime témoin $\left(T_{2}\right)$ proche du régime $T_{1}$ a été comparé au même régime additionné de graisses animales et d'huiles végétales encapsulées par une coque protéique (LE). Les teneurs en acides gras totaux dans la matière sèche étaient de 2,5\% pour les régimes témoins et comprises entre 8,1 et $9,1 \%$ pour les régimes expérimentaux. Dans ces essais, la digestibilité de différents nutriments ainsi que le $\mathrm{pH}$, la concentration et la composition des acides gras volatils du liquide du rumen et la dégradation in sacco de la matière sèche et des parois végétales ont été mesurés.

La supplémentation lipidique a réduit la digestibilité de la matière organique, qui a été respectivement pour l'essai 1 de 76,4;67,8 et 68,8\% (régimes $T_{1}$, LNT et LC) et pour l'essai 2 de 74,1 et 
$68,1 \%$ (régimes $T_{2}$ et LE). Cette diminution a été due à une action très négative des lipides sur la digestion des parois végétales : la digestibilité du NDF a été de 69,1;53,7 et 57,3\% (régimes $T_{1}$ LNT et LC); 62,9 et 53,6\% (régimes $T_{2}$ et LE). Cette diminution est liée à celle de la concentration en acides gras volatils dans le liquide du rumen, mesurée avant repas : 67,$4 ; 46,7$ et 47,7 mmol.t- ${ }^{-1}$ pour les régimes $T_{1}, L N T$ et $L C ; 61,1$ et $54,6 \mathrm{mmol} .^{-1}$ pour les régimes $T_{2}$ et $L E$. Les proportions d'acétate et de butyrate diminuent et celle de propionate augmente avec la supplémentation lipidique. En revanche, celle-ci n'a qu'un léger effet négatif sur la dégradation de la matière sèche et des parois végétales in sacco.

vache / digestion / lipides "protégés»

\section{INTRODUCTION}

Lipid supply in ruminant diets often has a negative effect on ruminal digestion, especially on fiber. This effect is more marked with polyunsaturated fatty acids and reduced by an appropriate calcium supply (Palmquist and Jenkins, 1980; Bauchart et al, 1985). Lipids decrease the rate of digestion of dry matter (Kowalczyk et al, 1977) and modify the volatile fatty acid pattern by increasing propionate, in relation with a more negative action on cellulolytic than on amylolytic bacteria (Maczulak et al, 1981). Experimental results, however, vary substantially from one trial to another. Factors of variation such as level of supplementation, rhythm of distribution of lipids or nature of basal diet have not been extensively studied. In particular, few data on the consequences of lipid supply have been obtained when maize silage was given as the only forage.

In order to reduce or eliminate negative effects of fat on digestion, different methods of protection have been proposed (Doreau et al, 1989). The oldest known method is the encapsulation of fat inside formaldehyde-treated proteins. This method was found to be efficient in vitro in some experiments, but in commercial products, protection against biohydrogenation is generally less complete and lipids are probably less inert in the rumen than in products made for experimentation. More- over, in vivo protection is generally lower than in vitro, owing to the effect of chewing on the physical structure of the product (Storry et al, 1980). Another method of protection is the use of crystalline fats such as free fatty acids, commonly known as "prilled fats", which are sometimes coated with starch. These products, having a high melting point, are theoretically insoluble in the rumen, but fatty acids are available for intestinal digestion (Grummer, 1988). Only a few trials have been performed with such "protected fats".

The purpose of the present experiments is two-fold: to determine the general effects of fats with diets based on maize silage in dairy cows, and to evaluate the effects of two sources of "protected fats" in their commercial form: encapsulated lipids and crystalline fat, in comparison with control diet or untreated fat. All fat sources were sold in France in 1986.

\section{MATERIALS AND METHODS}

\section{Animals, experimental designs and diets}

Trial 1: Three Holstein dairy cows in late lactation, fitted with ruminal cannulas, were used in a $3 \times 3$ latin square. Each period lasted 4 weeks: 3 of adaptation to the diet, 1 of measurements. Cows received 3 diets based on maize silage, differing by the nature of energy concentrate, supplemented with fat or not (table I). Energy 
Table I. Centesimal composition of the diets.

\begin{tabular}{|c|c|c|c|c|c|}
\hline \multirow[b]{2}{*}{ Diet } & \multicolumn{3}{|c|}{ Trial 1} & \multicolumn{2}{|c|}{ Trial 2} \\
\hline & C1 & $U F$ & $C F$ & $C 2$ & $E F$ \\
\hline Maize silage & 63.0 & 58.3 & 58.3 & 63.0 & 60.0 \\
\hline Energy concentrate 1 & 32.0 & - & 29.6 & 29.1 & 27.7 \\
\hline Formaldehyde-treated cake 2 & 5.0 & 4.7 & 4.7 & 7.9 & - \\
\hline Concentrate added with bone fat ${ }^{3}$ & - & 37.0 & - & - & - \\
\hline Crystalline fat & - & - & 7.4 & - & - \\
\hline Encapsulated fat & - & - & - & - & 12.3 \\
\hline
\end{tabular}

\footnotetext{
1 Composition in g/kg: barley 250 , beet pulp 250 , corn glutenfeed 250 , wheat bran 150 , urea 37.5 , beet molasses 37.5 , calcium chloride 5 , monocalcium phosphate 5 , magnesium oxide 5 , magnesium sulphate 5 , sodium chloride 5 ; ${ }^{2}$ Composition in $\mathrm{g} / \mathrm{kg}$ : soybean 500 , rapeseed $500 ;{ }^{3}$ Composition in $\mathrm{g} / \mathrm{kg}$ : bone fat 200 , barley 200 , beet pulp 200 , corn glutenfeed 200 , wheat bran 120 , urea 30 , beet molasses 30 , calcium chloride 4 , monocalcium phosphate 4 , magnesium oxide 3 , magnesium sulphate 4, sodium chloride 4, betahydroxytoluene 1 .
}

concentrate of the control diet $\mathrm{C} 1$ comprised various carbohydrate sources, urea, and calcium and magnesium in forms theoretically soluble in the rumen. Diet UF contained a concentrate made by the incorporation of an untreated fat, ie crude bovine bone fat, such as triglycerides (Bovozol, Union Protéine, Paris, France) in energy concentrate of diet $\mathrm{C} 1$. This concentrate supplied with fat was pelleted. Diet CF was made by the association of concentrate of diet C1 with a crystallized fat principally originating from lard obtained by cold-air spray crystallisation and coated with starch (Alikon, Alifet, Bützburg, Switzerland). All diets contained formaldehyde-treated cakes.

Trial 2: Three Holstein dairy cows in late lactation, fitted with rumen cannulas, received, in a cross-over design, 2 diets in 2 successive 4 week periods: 3 of adaptation to the diets, 1 of measurements. Trial 2 started 1 month after trial 1. Diets were based on maize silage. Energy concentrate of control diet $\mathrm{C} 2$ was the same as that in diet $\mathrm{C} 1$. In diet EF, concentrate of diet $\mathrm{C} 1$ was associated with a mixture of animal fat and vegetable oils encapsulated by formaldehydetreated proteins (Prolip, COFNA, Tours, France). Diet C2 only contained formaldehydetreated cakes in order to equilibrate nitrogen content of the 2 diets, since encapsulated fat contained treated proteins.
Proximate and fatty acid composition of diets are reported in table II. Crystalline fat contained $92 \%$ fat; encapsulated fat contained $64 \%$ fat and $34 \%$ protein. It was observed that fatty acids, which are commonly found in lipid sources for ruminants represented only $70 \%$ of total tatty acids in diet CF. Indeed, the chromatography of the crystalline fat displayed $34.6 \%$ of minor fatty acids or unidentified peaks, which were perhaps oxidation products of native fatty acids. Main identified fatty acids were palmitic, oleic and linoleic acids for crystalline fat $(25.4,21.0$ and $12.3 \%$ respectively) and palmitic and oleic acids for encapsulated fat (38.4 and $43.6 \%$ respectively). The very high ratio (close to 1) between fatty acids and total lipids, extracted as subsequently described, suggested that lipids of crystalline fat and encapsulated fat were mainly in the form of fatty acids.

\section{Feeding}

In both trials, feeds were given in limited amounts. Fat was given as a supplement: 0.6 and $0.8 \mathrm{~kg} / \mathrm{d}$ for trials 1 and 2 respectively. Rations were calculated so that, in a similar trial, diets provide the same amount of each component of the ration (fat in the supplement being excluded). Cows receiving control diets were fed 
Table II. Chemical composition of diets.

\begin{tabular}{|c|c|c|c|c|c|}
\hline \multirow[b]{2}{*}{ Diet } & \multicolumn{3}{|c|}{ Trial 1} & \multicolumn{2}{|c|}{ Tiral 2} \\
\hline & $c 1$ & $U F$ & $C F$ & $C 2$ & $E F$ \\
\hline \multicolumn{6}{|c|}{ Composition (\% DM) } \\
\hline Organic matter & 94.3 & 94.1 & 94.7 & 94.3 & 94.8 \\
\hline Crude protein & 15.1 & 15.5 & 14.0 & 15.8 & 16.2 \\
\hline Crude fiber & 14.9 & 13.8 & 13.8 & 14.9 & 13.6 \\
\hline NDF & 49.9 & 45.1 & 46.2 & 49.5 & 44.7 \\
\hline ADF & 18.0 & 16.4 & 16.6 & 17.9 & 16.2 \\
\hline Fatty acids & 2.5 & 8.1 & 9.0 & 2.5 & 9.1 \\
\hline \multicolumn{6}{|c|}{$\begin{array}{l}\text { Composition of fatty acids } \\
\text { ( } \mathrm{g} / 100 \mathrm{~g} \text { of total fatty acids) }\end{array}$} \\
\hline C 16:0 & 17.0 & 21.1 & 23.3 & 16.9 & 33.3 \\
\hline C 16: $1 \mathrm{n}-7$ & 0.8 & 3.9 & 4.4 & 0.9 & 3.0 \\
\hline C 18: 0 & 5.4 & 14.0 & 17.0 & 5.5 & 5.4 \\
\hline C 18: $1 n-9$ & 25.8 & 38.9 & 15.7 & 26.1 & 39.5 \\
\hline C 18: $2 n-6$ & 37.2 & 13.0 & 10.3 & 36.9 & 11.6 \\
\hline C $18: 3 n-3$ & 3.9 & 1.6 & 1.0 & 3.9 & 1.0 \\
\hline
\end{tabular}

according to their theoretical requirements, calculated at the beginning of the trial, assuming a monthly decrease of milk yield of $10 \%$. In the two trials, cows received daily $150 \mathrm{~g}$ of a mineral and vitaminic premix containing $20 \% \mathrm{Ca}$, $10 \% \mathrm{P}$ and $5 \% \mathrm{Mg}$ in addition to the diets.

The different parts of the diet were mixed and given twice daily (0800 and 16 30).

\section{Measurements and analyses}

Organic matter was determined by ashing at $550{ }^{\circ} \mathrm{C}$ for $6 \mathrm{~h}$, crude protein content by way Kjeldahl method, crude fiber by the method of Weende, NDF and ADF according to Goering and Van Soest (1970). Fatty acids were extracted in chloroform: methanol 2:1 (vol:vol) according to the method of Folch et al (1957) then in hexane: ethanol: $\mathrm{HCl}$ 5:2:2 (vol:vol:vol). They were saponified in $10 \%$ ethanol- $\mathrm{KOH}$ and then methylated in $3 \%$ methanol- $\mathrm{HCl}$. Their amount and composition were determined by GLC on a glass capillary column coated with FFAP, using an internal standard (Bauchart et al, 1987).
Diet digestibility was measured by total faeces collection during 6 days. Amounts of ash, crude fiber, NDF and ADF in feeds and representative samples of faeces were determined by the above-mentioned methods.

Ruminal liquid samples were taken for 2 consecutive days at $0800,0930,1130$ and 1430 , ie immediately before the morning feeding, and then $1.5,3.5$ and $6.5 \mathrm{~h}$ after feeding. $\mathrm{pH}$ was measured, and samples of the two consecutive days were pooled and frozen until analyses. Orthophosphoric acid was used as a conservative. Volatile fatty acid (VFA) concentration and composition was determined by gas chromatography (Jouany, 1982). On samples of trial 2, ammonia nitrogen was determined by a colorimetric technique (Van Eenaeme et al, 1969).

Nylon bags (model F 100, Tripette et Renaud, France, pore size $20 \times 60 \mu \mathrm{m}$ ) were filled with $3 \mathrm{~g}$ maize silage without cobs. Fifteen bags were introduced into the rumen at 0800 and removed by groups of 3 after $3,6,12,24$ and $48 \mathrm{~h}$ of incubation in the rumen. Bags were immediately washed in cold water, dried at $80^{\circ} \mathrm{C}$ for $48 \mathrm{~h}$ and weighed, in order to determine DM disappearance. Residues of the same period of in- 
cubation and of the same diet were pooled for determination of ADF and NDF. Individual data of ADF and NDF residues in bags were calculated from these analyses. Data of DM, ADF and NDF disappearance were pooled for a similar diet then adjusted to the exponential model described by Orskov and McDonald (1979): $D(t)=$ $a+b\left(1-e^{-c t}\right)$, in which degradation $D$ is a function of time $\mathrm{t}$; $\mathrm{a}, \mathrm{b}$ and $\mathrm{c}$ being considered as rapidly degradable fraction, slowly degradable fraction and mean rate of degradation of fraction b, respectively.

Statistical analyses were performed by analyses of variance in the latin square design in trial 1 or by comparison of means in trial 2 .

\section{RESULTS}

\section{Digestibility}

Dry matter and organic matter digestibility (table III) were significantly higher in control diets than in experimental diets in period 1. Although no direct comparison was possible between diets of different trials, there was no apparent difference between the two control diets, as between the experimental diets of trials 1 and 2 .

Table III. Digestibility coefficients of the different diets.

\begin{tabular}{|c|c|c|c|c|c|}
\hline \multirow[b]{2}{*}{ Diet } & \multicolumn{3}{|c|}{ Trial 1} & \multicolumn{2}{|c|}{ Trial 2} \\
\hline & $c_{1}$ & $U F$ & $C F$ & $C 2$ & $E F$ \\
\hline $\begin{array}{l}\text { Feed intake without } \\
\text { lipid supplement (kg DM) }\end{array}$ & 7.8 & 7.9 & 7.8 & 10.3 & 10.3 \\
\hline Lipid supplement (kg) & - & 0.6 & 0.6 & - & 0.8 \\
\hline \multicolumn{6}{|l|}{$\begin{array}{l}\text { Digestibility } \\
\text { coefficient (\%) }\end{array}$} \\
\hline Dry matter & $\begin{array}{l}73.7^{\mathrm{A}} \\
\pm 2.8\end{array}$ & $\begin{array}{l}65.2^{\mathrm{B}} \\
\pm 1.7\end{array}$ & $\begin{array}{l}65.9^{\mathrm{B}} \\
\pm 1.5\end{array}$ & $\begin{array}{r}71.6 \\
\pm 2.8\end{array}$ & $\begin{array}{r}66.7 \\
\pm 1.6\end{array}$ \\
\hline Organic matter & $\begin{array}{l}76.4^{\mathrm{A}} \\
\pm 2.9\end{array}$ & $\begin{array}{c}67.8^{\mathrm{B}} \\
\pm 1.8\end{array}$ & $\begin{array}{c}68.8^{\mathrm{B}} \\
\pm 1.7\end{array}$ & $\begin{array}{r}74.1 \\
\pm 3.0\end{array}$ & $\begin{array}{r}68.1 \\
\pm 3.0\end{array}$ \\
\hline Crude fiber & $\begin{array}{l}63.6^{A} \\
\pm 8.1\end{array}$ & $\begin{array}{l}41.8^{B} \\
\pm 6.0\end{array}$ & $\begin{array}{l}43.1^{\mathrm{B}} \\
\pm 4.7\end{array}$ & $\begin{array}{l}62.9^{a} \\
\pm 7.7\end{array}$ & $\begin{array}{l}48.9 b \\
\pm 3.0\end{array}$ \\
\hline NDF & $\begin{array}{l}69.1^{a} \\
\pm 6.8\end{array}$ & $\begin{array}{l}53.7^{b} \\
\pm 3.5\end{array}$ & $\begin{array}{l}57.3^{b} \\
\pm 5.6\end{array}$ & $\begin{array}{l}62.9^{\mathrm{a}} \\
\pm 6.6\end{array}$ & $\begin{array}{l}53.6^{\mathrm{b}} \\
\pm 1.9\end{array}$ \\
\hline ADF & $\begin{array}{r}57.4 \\
\pm 9.1\end{array}$ & $\begin{array}{r}37.7 \\
\pm 7.3\end{array}$ & $\begin{array}{r}40.1 \\
\pm 8.2\end{array}$ & $\begin{array}{r}54.8 \\
\pm 7.6\end{array}$ & $\begin{array}{r}43.6 \\
\pm 4.0\end{array}$ \\
\hline (NDF - ADF) & $\begin{array}{l}75.7^{a} \\
\pm 5.8\end{array}$ & $\begin{array}{l}62.8^{b} \\
\pm 1.5\end{array}$ & $\begin{array}{l}66.9^{b} \\
\pm 4.3\end{array}$ & $\begin{array}{r}68.4 \\
\pm 7.0\end{array}$ & $\begin{array}{r}60.3 \\
\pm 4.2\end{array}$ \\
\hline NDS & $\begin{array}{l}84.2^{A} \\
\pm 0.8\end{array}$ & $\begin{array}{l}80.6^{\mathrm{B}} \\
\pm 1.0\end{array}$ & $\begin{array}{l}79.3^{B} \\
\pm 0.8\end{array}$ & $\begin{array}{r}84.4 \\
\pm 1.3\end{array}$ & $\begin{array}{r}81.6 \\
\pm 1.7\end{array}$ \\
\hline
\end{tabular}

Statistical analyses were performed separately for the two trials. Different letters on the same row indicate significant differences between diets $(A, B: P<0.01 ; a, b=P<0.05)$. 
Fiber digestibility was significantly higher for control diets than for experimental diets. The difference was more important when fiber was taken as crude fiber (by about 21 percentage units for trial 1 and 13 percentage units for trial 2) than as NDF (by about 14 percentage units for trial 1 and 9 percentage units for trial 2). This difference was mainly due to both lignocellulose, estimated by ADF residue, and hemicelluloses estimated by the difference between NDF and ADF residues. A part of the difference in organic matter digestibility is due to variation in digestibility of neutral detergent soluble (NDS) fraction: lipid supply decreased it by about 4 percentage units for trial $\uparrow$ and 3 percentage units for trial 2.

\section{$\mathrm{pH}$ and end products in ruminal fluid}

A significant difference between diets was observed in trial 1 for $\mathrm{pH}$ and total VFA concentration before feeding (table IV). At 0800 , the $\mathrm{pH}$ value was very high and VFA concentration was very low for diets UF and CF. At the subsequent hours of sampling, the trends towards a lower VFA concentration when fat was added were not significant.

Lipid supply involved a decrease in proportion of acetate and butyrate in total VFA. Differences were significant $1.5 \mathrm{~h}$ after feeding for acetate in trial 1, 1.5 and $3.5 \mathrm{~h}$ after feeding for butyrate in trial 1 and 3.5 and $6.5 \mathrm{~h}$ after feeding for butyrate in trial 2. The decrease in butyrate in trial 1 was more marked with diet CF than with diet UF. A significant increase in propionate was observed when fat was added in both trials, except before feeding.

In trial 2, ammonia nitrogen greatly varied with the time of sampling but not with diet. Mean concentrations at 0800,0930 ,
1130 and 1430 were 38.6, 191.2, 99.1, 19.6 and $42.9,138.0,72.9,20.9 \mathrm{mg} / 100$ $\mathrm{ml}$ for diets $\mathrm{C} 2$ and $\mathrm{EF}$ respectively.

\section{In sacco degradation}

Dry matter diseappearance of maize silage in nylon bags (fig 1) did not significantly differ between diets in trial 1 as in trial 2 at the 5 periods of sampling, although a trend was observed, showing a lower degradation when fat was added. Modelling the data (table V) showed that the degradation rate was lower for diets rich in fat than for control diets.

The same trends were observed on cell wall disappearance. No significant effect was shown at the 4 hours of sampling for trial 2. In trial 1, after 6 hours of incubation in the rumen, disappearance of NDF, ADF and (NDF - ADF) fractions was significantly lower for diet CF than for diets $\mathrm{C} 1$ and UF. No significant difference occurred after 12,24 or $48 \mathrm{~h}$ of incubation. As for DM, the difference was due to a variation in degradation rate.

\section{DISCUSSION}

The more surprising result of these experiments is the extent of the drop in digestibility of organic matter and cell walls when fat was added to a diet. Such a negative effect of fat has only been shown in a few experiments with different sources of fat: Devendra and Lewis, 1974; Ikwuegbu and Sutton, 1982, in sheep and Moore et al (1986) in steers, with maize oil, linseed oil and animal fat, respectively. No common experimental condition has been found within these experiments. The amount of fatty acids in the diet was high in these trials, but other data have shown no nega- 
Table IV. Rumen $\mathrm{pH}$ and VFA: variations with time after feeding.

\begin{tabular}{|c|c|c|c|c|c|}
\hline \multirow[b]{2}{*}{ Diet } & \multicolumn{3}{|c|}{ Trial 1} & \multicolumn{2}{|c|}{ Trial 2} \\
\hline & C1 & UF & $C F$ & C2 & $E F$ \\
\hline \multicolumn{6}{|l|}{$p H$} \\
\hline $\mathrm{Oh}$ & $7.0^{\mathrm{a}} \pm 0.1$ & $7.3^{b} \pm 0.1$ & $7.3^{b} \pm 0.1$ & $7.1 \pm 0.1$ & $7.1 \pm 0.3$ \\
\hline $1.5 \mathrm{~h}$ & $6.7 \pm 0.1$ & $6.6 \pm 0.1$ & $6.8 \pm 0.1$ & $6.7 \pm 0.1$ & $6.7 \pm 0.1$ \\
\hline $3.5 \mathrm{~h}$ & $6.6 \pm 0.1$ & $6.5 \pm 0.1$ & $6.6 \pm 0.1$ & $6.5 \pm 0.2$ & $6.5 \pm 0.1$ \\
\hline $6.5 \mathrm{~h}$ & $6.7 \pm 0.1$ & $6.7 \pm 0.1$ & $6.7 \pm 0.3$ & $6.6 \pm 0.1$ & $6.6 \pm 0.1$ \\
\hline \multicolumn{6}{|c|}{$V F A(m M)$} \\
\hline $\mathrm{Oh}$ & $67.4^{a} \pm 8.7$ & $46.7^{b} \pm 10.8$ & $47.7^{b} \pm 6.4$ & $61.1 \pm 3.6$ & $54.6 \pm 12.6$ \\
\hline $1.5 \mathrm{~h}$ & $98.2 \pm 11.0$ & $90.1 \pm 10.6$ & $85.2 \pm 15.4$ & $92.3 \pm 4.1$ & $88.1 \pm 1.2$ \\
\hline $3.5 \mathrm{~h}$ & $96.2 \pm 4.0$ & $89.6 \pm 8.0$ & $87.4 \pm 11.2$ & $104.2 \pm 11.9$ & $85.2 \pm 10.9$ \\
\hline $6.5 \mathrm{~h}$ & $89.2 \pm 3.8$ & $73.6 \pm 10.8$ & $81.3 \pm 19.3$ & $101.3 \pm 5.5$ & $89.8 \pm 5.4$ \\
\hline \multicolumn{6}{|c|}{$\begin{array}{l}\text { Acetate } \\
(\mathrm{mol} / 100 \mathrm{~mol})\end{array}$} \\
\hline $\mathrm{Oh}$ & $69.4 \pm 1.1$ & $66.4 \pm 2.1$ & $67.1 \pm 3.6$ & $69.3 \pm 0.5$ & $67.5 \pm 4.1$ \\
\hline $1.5 \mathrm{~h}$ & $62.7^{a} \pm 0.1$ & $59.8^{b} \pm 1.2$ & $61.0^{\mathrm{ab}} \pm 2.5$ & $65.7 \pm 1.0$ & $60.3 \pm 1.0$ \\
\hline $3.5 \mathrm{~h}$ & $64.3 \pm 0.6$ & $60.7 \pm 0.6$ & $61.5 \pm 3.0$ & $62.6 \pm 2.1$ & $60.3 \pm 1.2$ \\
\hline $6.5 \mathrm{~h}$ & $66.5 \pm 1.1$ & $62.0 \pm 1.0$ & $62.0 \pm 3.2$ & $64.7 \pm 1.8$ & $61.6 \pm 1.8$ \\
\hline \multicolumn{6}{|c|}{$\begin{array}{l}\text { Propionate } \\
\text { (mol/100 mol) }\end{array}$} \\
\hline $\mathrm{Oh}$ & $14.9 \pm 0.5$ & $18.1 \pm 1.1$ & $17.6 \pm 3.0$ & $15.9 \pm 1.7$ & $19.0 \pm 2.8$ \\
\hline $1.5 \mathrm{~h}$ & $20.1^{a} \pm 0.8$ & $26.6^{b} \pm 1.3$ & $25.4^{b} \pm 2.7$ & $19.3^{A} \pm 0.7$ & $26.2^{\mathrm{B}} \pm 2.0$ \\
\hline $3.5 \mathrm{~h}$ & $18.8^{a} \pm 0.3$ & $24.1^{b} \pm 1.2$ & $24.6^{\mathrm{ab}} \pm 3.4$ & $20.3^{a} \pm 1.8$ & $25.5^{b} \pm 1.1$ \\
\hline $6.5 \mathrm{~h}$ & $16.7^{a} \pm 0.4$ & $21.6^{a b} \pm 1.8$ & $23.5^{b} \pm 3.9$ & $18.4^{a} \pm 1.7$ & $24.0^{b} \pm 1.2$ \\
\hline \multicolumn{6}{|c|}{$\begin{array}{l}\text { Butyrate } \\
\text { (mol/100 mol) }\end{array}$} \\
\hline $\mathrm{Oh}$ & $11.1 \pm 1.7$ & $9.6 \pm 0.6$ & $10.3 \pm 1.0$ & $10.6 \pm 1.7$ & $8.5 \pm 0.9$ \\
\hline $1.5 \mathrm{~h}$ & $11.9^{\mathrm{a}} \pm 1.1$ & $9.4^{b} \pm 0.9$ & $8.6^{c} \pm 0.9$ & $11.8 \pm 0.2$ & $9.2 \pm 1.5$ \\
\hline $3.5 \mathrm{~h}$ & $12.4^{\mathrm{a}} \pm 0.9$ & $10.9^{b} \pm 0.6$ & $9.1^{c} \pm 0.4$ & $13.5^{\mathrm{a}} \pm 0.7$ & $9.8^{b} \pm 1.2$ \\
\hline $6.5 \mathrm{~h}$ & $13.1 \pm 1.3$ & $12.5 \pm 1.7$ & $10.7 \pm 1.2$ & $13.7^{A} \pm 0.5$ & $10.0^{B} \pm 1.2$ \\
\hline
\end{tabular}

Statistical analyses were performed separately for the two trials. Different lefters on the same row indicate significant differences between diets (A,B: $P<0.01 ; \mathrm{a}, \mathrm{b}: P<0.05)$. 
Table V. Disappearance of dry matter (DM) and cell walls in sacco.

\begin{tabular}{|c|c|c|c|c|c|}
\hline \multirow[b]{2}{*}{ Diet } & \multicolumn{3}{|c|}{ Trial 1} & \multicolumn{2}{|c|}{ Trial 2} \\
\hline & $\mathrm{Cl}$ & $U F$ & $C F$ & $\mathrm{C} 2$ & $E F$ \\
\hline \multicolumn{6}{|l|}{$\mathrm{DM}$} \\
\hline a & 42.1 & 44.1 & 42.4 & 43.7 & 44.8 \\
\hline $\mathrm{b}$ & 32.0 & 34.5 & 40.0 & 42.3 & 54.5 \\
\hline c & 0.0544 & 0.0300 & 0.0331 & 0.0368 & 0.0139 \\
\hline \multicolumn{6}{|l|}{ NDF } \\
\hline a & 7.1 & 15.6 & 13.6 & 15.5 & 15.1 \\
\hline $\mathrm{b}$ & 56.9 & 55.1 & 63.6 & 66.7 & 56.1 \\
\hline c & 0.0563 & 0.0260 & 0.0287 & 0.0325 & 0.0251 \\
\hline \multicolumn{6}{|l|}{ ADF } \\
\hline a & 11.0 & 10.3 & 9.0 & 8.9 & 8.4 \\
\hline$b$ & 75.6 & 66.9 & 94.5 & 70.7 & 66.8 \\
\hline c & 0.0181 & 0.0177 & 0.0143 & 0.0310 & 0.0203 \\
\hline \multicolumn{6}{|c|}{ (NDF - ADF) } \\
\hline a & 18.4 & 21.1 & 19.3 & 22.2 & 22.5 \\
\hline b & 47.9 & 48.2 & 54.8 & 61.6 & 49.0 \\
\hline c & 0.0616 & 0.0373 & 0.0416 & 0.0362 & 0.0307 \\
\hline
\end{tabular}

a: rapidly degraded fraction (\%); b: slowly degraded fraction (\%); c: mean rate of degradation of b $\left(h^{-1}\right)$.

tive effect of lipid with more than $8 \%$ fatty acids in the diet (Palmquist and Conrad, 1980; Van der Honing et al, 1983; Doreau et al, 1987). It appears that the amount and nature of fatty acids are not the only factors of variation of digestibility disturbances of diets rich in fat. In a recent experiment carried out in our laboratory, the effect of rapeseed oil on OM and cell wall digestibility was more negative for a maize silage-based diet than for a hay-based diet (Ben Salem, 1989). Although it is often thought that high fiber diets are more convenient for lipid addition than low fiber diets (Palmquist and Jenkins, 1980), there is no experimental evidence to confirm this matter: Cottyn et al (1971) and Johnson and McClure (1972) did not show an effect of percentage of concentrate in the diet on digestibility depression when fat was added.

Another surprising remark is that we did not reproduce the same results in a separate trial carried out on 2 groups of 6 midlactating cows with diets comparable to $\mathrm{C} 2$ and EF (Chilliard and Doreau, unpublished data). The control diet was also based on maize silage and encapsulated fat given in the same proportion as that in trial 2 . Feed intake without lipid supplement was $14.0 \mathrm{~kg}$ DM. However, this supplementary fat was introduced via rumen cannula. $O M$ digestibility was 66.8 and $71.0 \%$ and crude fiber digestibility was 51.9 and $50.7 \%$ for control and experimental diets respectively. Two hypotheses can be proposed: in the latter trial, OM digestibility of control diet was lower than in trial 2, owing either 

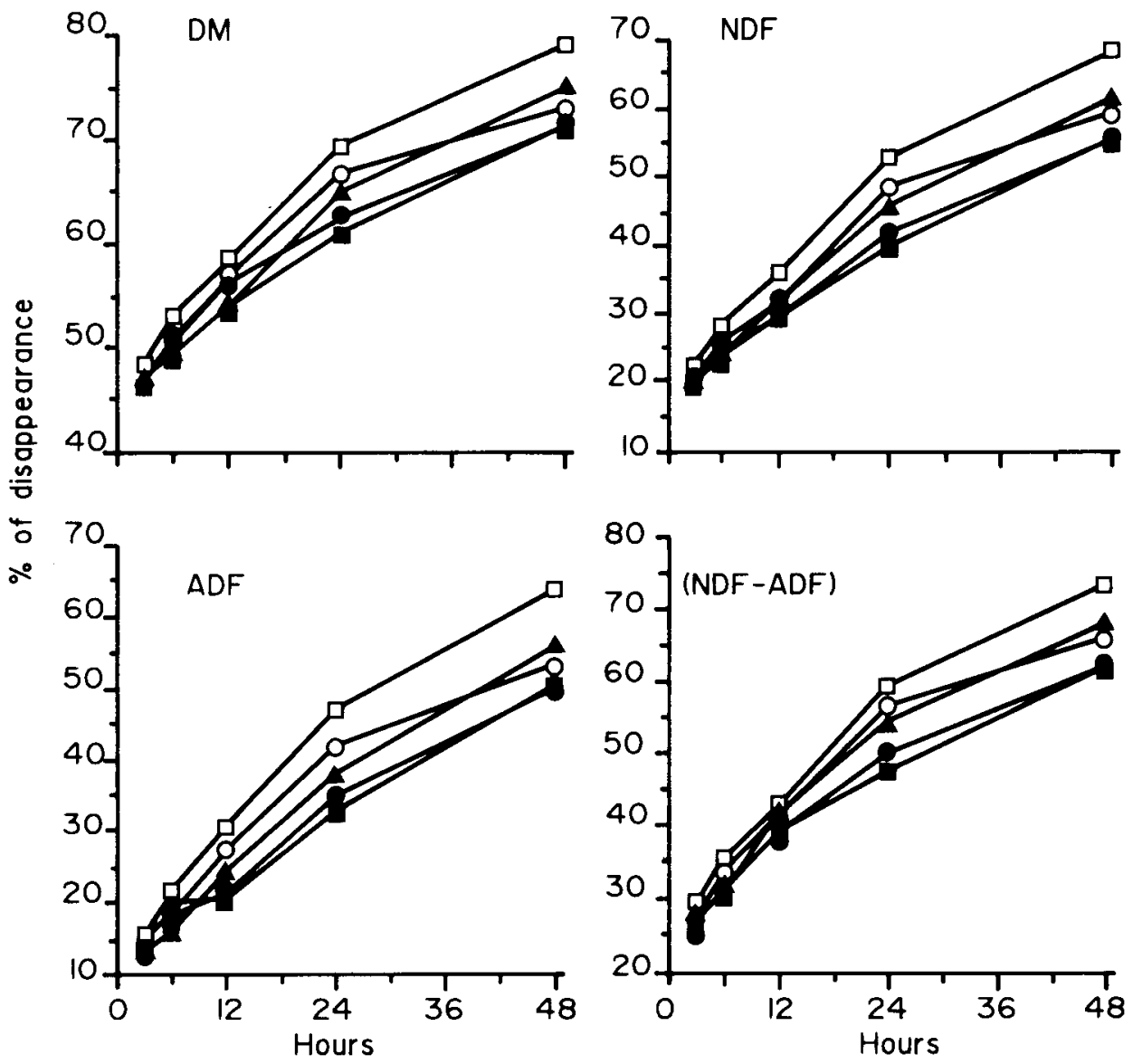

Fig 1. Disappearance of dry matter and cell wall constituents in nylon bags. $-\mathrm{O}-\mathrm{C1}$; $\longrightarrow$ UF; $-\Delta-\mathrm{CF} ;-\mathcal{Z}-\mathrm{C} 2$; - $-\mathrm{EF}$.

to a lower nutritive value of maize silage or probably to a higher feed intake, which would explain the difference (Doreau et al, 1988) and involves a lower retention time of solid particles in the rumen; in the latter trial, encapsulated fat was not chewed during intake, and probably little ruminated. As a consequence, its physical structure was less altered. The first hypothesis needs to be supported by experimental data, since no direct experimental proof exists. The role of rate of passage in the extent in ruminal disturbances with diets rich in fat can be suggested; however, it cannot explain the interactions between basal diets and oil supplement in the trial of Ben Salem (1989) where rates of passage were unaltered.

The positive effect of bivalent cations soluble in the rumen did not appear in this experiment. It is surprising, since the degree of formation of calcium soaps from calcium chloride in the rumen is high (Jenkins and Palmquist, 1982) and the dissociation of these soaps at pH 6.5 is low (Sukhija and Palmquist, 1990). 
The decrease in digestibility with diets supplemented in lipids is related to the decrease in VFA concentration. However, the latter did not occur in the hours after feeding. The decrease in in sacco degradation with diets rich in fat was too slight to explain the decrease in digestibility. A decrease in solid retention time in the rumen when fat is added to the diet has only been observed by Boggs et al (1987).

The orientation of ruminal fermentation towards propionic acid when fat is added is a classical result. As in Sutton et al (1983) or Cottyn et al (1989), this variation was explained by decreases both in acetic and butyric acid as a result of less cellulolytic activity. The decrease in NDS digestibility in trial 1 when fat was added was probably not related to a decrease in starch digestion: indeed, propionic acid concentration in rumen juice does not decrease, fat does not impair amylolytic activity of rumen juice (Ben Salem, 1989) and a possible decrease in ruminal starch digestion could be compensated in the small intestine (Doreau and Rémond, 1982).

The degree of "protection" of crystalline fat is probably low. Aeschbacher (1984) observed a slight increase in fiber digestibility with a crystalline fat supply: however, the experimental diet had a higher content in protein and concentrates than the control diet and digestibility was measured using a marker. Other experiments carried out with the same kind of fat showed a slight decrease in crude fiber digestibility when compared to a control diet, but unprotected fat had the same low effect (Daccord, 1987) or no negative effect (Abel et al, 1988). Prilled fats did not decrease ruminal digestion in 2 trials (Grummer, 1988, Schauff and Clark, 1989), but in these experiments there was no diet containing unprotected fat. It appears that more research is needed on the digestion of diets containing crystalline fats.
Although in trial 2 there was no diet containing untreated fat, the comparison with diets of trial 1 allows us to believe that the degree of protection of encapsulated fat is low. Generally, experiments carried out with encapsulated fat have shown an effective "protection" as assessed by the absence of degradation, measured in vitro, and the high content in polyunsaturated fatty acids in milk (Fogerty and Johnson, 1980). In some cases "protection" has been found to be partial (Sutton et al, 1983). The lack of effect of encapsulation in our trial is perhaps due to the fact that a commercial product was used, or to the technology of encapsulation, which depends on the manufacturer. However, an in vitro measurement of nitrogen degradability of the encapsulated fat used in this experiment showed a high protection against ruminal degradation of protein (J Aufrère, personal communication). The lack of protection of lipids in the product is probably due to a physical breakdown caused by mastication, and overpasses the chemical links in protein fraction created by formaldehyde treatment. If this phenomenon is correct it could explain the absence of decrease in fiber digestibility observed in the above-mentioned unpublished trial, in which encapsulated fat was supplied via a rumen cannula.

\section{ACKNOWLEDGMENTS}

The authors thank Union Protéine (Paris, France) for their financial support and Alifet (Bützburg, Switzerland) for providing crystalline fat.

\section{REFERENCES}

Abel HJ, Abd El Ati N, Abd El Hafiz G, Abd ElRazek M, El-Din T, El-Shazly K (1988) Investigations on the nutritional value for rumi- 
nants of various fats. Anim Feed Sci Technol $19,111-120$

Aeschbacher G (1984) "Kristallines Fett". Inaug Diss Dokt Vet Med Univ Bern, Switzerland, $88 \mathrm{pp}$

Bauchart D, Doreau M, Kindler A (1987) Effect of fat and lactose supplementation on digestion in dairy cows. 2 . Long-chain fatty acids. $J$ Dairy Sci 70, 71-80

Bauchart D, Doreau M, Legay-Carmier F (1985) Utilisation digestive des lipides et conséquences de leur introduction sur la digestion du ruminant. Bull Tech CRZV Theix, INRA 61, 65-77

Ben Salem H (1989) Effets de l'addition de matières grasses sur la digestibilité et la digestion des glucides et de l'azote chez la vache laitière. Influence de la composition de la ration. Thesis M Sci IAM Zaragoza, Spain, $70 \mathrm{pp}$

Boggs DL, Bergen WG, Hawkins DR (1987) Effect of tallow supplementation and protein withdrawal on ruminal fermentation, microbial synthesis and site of digestion. J Anim Sci 64, 907-914

Cottyn BG, Buysse FX, Boucqué ChV (1971) The effect of linseed oil fatty acids on digestibility and rumen fermentation. $Z$ Tierphysiol Tierernährg Futtermittelk 27, 252-259

Cottyn BG, Fiems LO, Boucqué ChV, Van den Broeke F, Buysse FX (1989) Characteristics of hydrolysed fat and lard and their effect on diet digestibility in sheep and bulls. J Anim Physiol Anim Nutr 62, 215-224

Daccord R (1987) Effect of addition of animal or vegetable fat to hay based diet on digestibility and nitrogen balance in the lactating goat. Ann Zootech (Paris) 36, 329 (abstr)

Devendra C, Lewis D (1974) The interaction between dietary lipids and fibre in the sheep. 2. Digestibility studies. Anim Prod 19, 67-76

Doreau M, Rémond B (1982) Comportement alimentaire et utilisation digestive d'une ration de composition constante chez la vache laitière en fin de gestation et début de lactation. Reprod Nutr Dév 22, 307-324

Doreau M, Bauchart D, Kindler A (1987) Effect of fat and lactose supplementation on digestion in dairy cows. 1. Nonlipid components. J Dairy Sci 70, 64-70
Doreau $M$, Adingra $K$, Rémond $B$, Chilliard $Y$ (1988) Effets respectifs "des quantités ingérées et du stade physiologique sur la digestibilité d'une même ration chez la vache laitière. Reprod Nutr Dév 28, suppl 1, 63-64

Doreau M, Ferlay A, Elmeddah Y, Bauchart D (1989) La "protection" des matières grasses utilisées dans l'alimentation des ruminants: conséquences sur la digestion. Rev Fr Corps Gras 6, 271-278

Fogerty AC, Jonhson AR (1980) Influence of nutritional factors on the yield and content of milk fat: protected polyunsaturated fat in the diet. In: Factors Affecting the Yield and Contents of Milk Constituents of Commercial Importance (Moore JH, Rook JAF, eds) 96-104

Folch J, Lees M, Sloane Stanley GH (1957) A simple method for the isolation and purification of total lipids from animal tissues. $J$ Biol Chem 226, 497-509

Goering HK, Van Soest DJ (1970) Forage Fiber Analyses. Agricultural Handbook No 379. Agricultural Research Service, USDA, Washington, DC, $20 \mathrm{pp}$

Grummer RR (1988) Influence of prilled fat and calcium salt of palm oil fatty acids on ruminal fermentation and nutrient digestibility. $J$ Dairy Sci 71, 117-123

Ikwuegbu OA, Sutton JD (1982) The effect of varying the amount of linseed oil supplementation on rumen metabolism in sheep. $\mathrm{Br} J$ Nutr 48, 365-375

Jenkins TC, Palmquist DL (1982) Effect of added fat and calcium on in vitro formation of insoluble fatty acid soaps and cell wall digestibility. J Anim Sci 55, 957-963

Johnson RR, McClure KE (1972) High fat rations for ruminants. I. The addition of saturated and unsaturated fats to high roughage and high concentrate rations. J Anim Sci 34, 501-509

Jouany JP (1982) Dosage des acides gras volatils et des alcools dans les contenus digestifs, les jus d'ensilage, les cultures bactériennes et les contenus de fermenteurs aérobies. Sci Alim 2, 131-144

Kowalczyk J, Orskov ER, Robinson JJ, Stewart CS (1977) Effect of fat supplementation on voluntary food intake and rumen metabolism in sheep. Br J Nutr 37, 251-257 
Maczulak AE, Dehority $B A$, Palmquist DL (1981) Effects of long-chain fatty acids on growth of rumen bacteria. Appl Environ Microbiol 42, 856-862

Moore JA, Swingle RS, Hale WH (1986) Effects of whole contonseed, cottonseed oil or animal fat on digestibility of wheat straw diets by steers. J Anim Sci 63, 1267-1273

Orskov ER, McDonald J (1979) The estimation of protein degradability in the rumen from incubation measurements weighted according to rate of passage. J Agric Sci Camb 92, 499-503

Palmquist DL, Conrad HR (1980) High fat rations for dairy cows. Tallow and hydrolyzed blended fat at two intakes. $J$ Dairy Sci 63, 391-395

Palmquist DL, Jenkins TC (1980) Fat in lactation rations. J Dairy Sci63, 1-14

Schauff DJ, Clark JH (1989) Effects of prilled fatty acids and calcium salts of fatty acids on rumen fermentation, nutrient digestibilities, milk production, and milk composition. $J$ Dairy Sci 72, 917-927
Storry JE, Brumby PE, Dunkley WL (1980) Influence of nutritional factors on the yield and content of milk fat: protected nonpolyunsaturated fat in the diet. In: Factors Affecting the Yield and Contents of Milk Constituents of Commercial Importance (Moore JH, Rook JAF, eds) 105-125

Sukhija PS, Palmquist DL (1990) Dissociation of calcium soaps of long-chain fatty acids in rumen fluid. J Dairy Sci 73, 1784-1787

Sutton JD, Knight R, McAllan AB, Smith RH (1983) Digestion and synthesis in the rumen of sheep given diets supplemented with free and protected oils. Br J Nutr 49, 419-432

Van der Honing $Y$, Tamminga $S$, Wieman BJ, Steg A, Van Donselaar B, Van Gils LGM (1983) Further studies on the effect of fat supplementation of concentrates fed to lactating dairy cows. 2 . Total digestion and energy utilization. Neth J Agric Sci 31, 27-36

Van Eenaeme C, Bienfait JM, Lambot O, Pondant A (1969) Détermination automatique de l'ammoniaque dans le liquide du rumen par la méthode de Berthelot adaptée à l'autoanalyzer. Ann Méd Vét 7, 419-429 